\title{
Viral Marketing Impact on Tourism and Hospitality Industry
}

\author{
Rehab Daif ${ }^{1}$, Khaled Elsayed $^{2 *}$ \\ ${ }^{1}$ Helwan University, Egypt, King Faisal University, KSA \\ ${ }^{2}$ Helwan University, Egypt, King Faisal University, KSA
}

*Corresponding Author: Khaled Elsayed, Helwan University, Egypt, King Faisal University, KSA

\begin{abstract}
Despite there are many tourism and hospitality organizations, it might be confusing for tourists to choose one over others. Studying the impact of viral marketing on choosing tourism and hospitality organizations is vital. In Egypt, the development of tourism and hospitality industry is vital for economy development. tourism and hospitality organizations should invest in innovative methods for marketing their services. The development of web 2.0, 3.0managed to have a great impact on the progress of viral marketing which is considered as a kind of online word-of-mouth and social networking. This paper is studying and assessing the benefit of viral marketing for tourism and hospitality organizations in Egypt. To achieve this aim, small and medium hotels and travel agencies will be investigated using qualitative approach. The results reveal the problems, advantages and disadvantages of tourism and hospitality organizations in applying viral marketing and its impact on tourists' behaviours. Therefore, this paper recommends some points related to using of viral marketing techniques which should be applied by tourism and hospitality organizations. Finally, a best practice model is presented to be used by academics and practitioners in the field of marketing tourism and hospitality services.
\end{abstract}

Keywords: Viral Marketing, tourism and hospitality organizations, Travel agencies, Hotels

\section{INTRODUCTION}

The importance of viral marketing for the tourism and hospitality industry has been documented by various author (Soteriades, 2011; Morais \& Mhando, 2012; Yeoh, Othman \& Ahmad, 2013) as they demonstrated that the most important marketing approach that tourism organizations use in communicating and influencing tourists is viral marketing. Viral marketing has changed the tourists' behaviour as it allows tourists to share information and experiences with others with no physical or time constraints (Khan, 2012). The tourist's behaviour in choosing a tourism destination has been affected directly by viral marketing (Morais \& Mhando, 2012).

With the introduction of Web 3.0, social media and technology have the powerful impact to influence tourist E-behaviours (Kaplan \& Haenlein, 2010). Therefore, it is important to explore viral marketing on tourism and hospitality organizations. Despite the importance of viral marketing on the tourism and hospitality industry, there are few studies exploring the relationship between viral marketing and tourists' behaviour (Soteriades, 2011). To address this lack, this research explores the way in which viral marketing affect tourist's behaviour in decision-making process by identifying the advantages and disadvantages of viral marketing to tourism and hospitality organizations. This work aims to contribute to the viral marketing study through understanding of the degree of knowledge of tourism and hospitality organizations and their vision on this phenomenon through collecting primary information through an interview with marketing managers in tourism and hospitality organizations in Egypt. This allowed the researchers to compare between the fundamentals described in the literature and the real situation of viral marketing in Egyptian tourism and hospitality organizations.

This research paper first outlines the importance of viral marketing. It then moves to review the related studies on viral marketing and its impact on tourism and hospitality organizations. It then provides the theoretical framework of the study. The paper moves to present the qualitative study regarding the factors influencing tourists' behaviour in choosing SMTE. Finally, the study conclusions, implications limitations and suggestion for future research are presented. 


\section{LITERATURE REVIEW}

Word of mouth (WOM) is the source of viral marketing which is defined as "oral communication between individuals who are not linked to the marketing of a service (Kadyan \& Aswal, 2014). The informal communication between people outside the company (e.g. family, friends) is influencing the tourists' intentions and their buying behaviour (Brown, Ham, \& Hughes, 2010). Moreover, information derived from non-commercial sources tends to be more influential in the formation of tourists' opinion than commercial sources (Chung, Lee, \& Han, 2015). On the other hand, there are several studies show that negative WOM has more influence than positive ones (He \& Harris, 2014).

Electronic word-of-mouth effect (eWOM) is positive or negative comments made by individuals outside the organization about specific services which may be available to several people through the internet (Litvin, Goldsmith \& Pan, 2017). It is considered as an important source of information for the tourists as it has a huge impact on them more than advertising on television, radio and newspapers. In addition, tourists are more likely to search for negative eWOM in a situation where there is a lack of information about specific service (Litvin, Goldsmith \& Pan, 2008).

The viral marketing term is going back to Steve Jurvertson and Tim Draper who wrote an article entitled "Viral Marketing" in which they described the practice of sending advertising emails from current tourists to others using Hotmail (Czepiec, Bryant, Roxas, \& Whitson, 2012). Tourists became "infected" with an advertising message, which was passed from one tourist to another as a flu virus (Rathore, Joshi, \& Ilavarasan, 2017). Viral marketing exploits existing social networks by encouraging tourists to share information about a product with their friends. The most important measure is the tourist's willingness to recommend a product or service to others (Litvin, Goldsmith \& Pan, 2008).

Web 3.0 is a concept originally initiated during a conference brainstorming session between O'Reilly and Media Live International in 2004 who described it as "an attitude rather than a technology" (O'Reilly, 2005). The key difference between traditional websites and Web 3.0 is the participation of the users. Web 3.0 sites could be the platform for users to interact and collaborate with each other (Stavrakantonakis, Toma, Fensel, \& Fensel, 2013). Travel 2.0 is a term that represents the extension and customization of the concept of Web 3.0 in the tourism sector. Travel 2.0 describes a new generation of travel websites with new technologies which enable social collaboration among travellers where tourists can share their experiences with fellow travellers (Stavrakantonakis, Toma, Fensel, \& Fensel, 2013). Tourists regard this information as more trustworthy and beneficial rather than professional travel advice that's why travellers are becoming increasingly more interested in seeking the opinions and reviews of the fellow travellers (Erragcha \& Romdhane, 2014).

In tourism, tourists' behaviour has always been influenced by development of technology, but Web 3.0 has completely changed how tourists design and consume travel related products (Stavrakantonakis, Toma, Fensel, \& Fensel, 2013). During the travel planning process social media get an important role, because it gives access to other travellers' experiences as an ultimate information source (Erragcha \& Romdhane, 2014).

In relation to Web 3.0 applications, viral marketing term was defined as the promotion of a company or its products and services through a persuasive message designed to spread, typically online, from person to person (Kirby \& Marsden, 2006). Viral marketing is "the marketing on the Internet that spreads a message rapidly" (Kalyanam, McIntyre, \& Masonis, 2007). Alexandra, Claudia, \& OctavIonut, (2011) indicate that the key driver in viral marketing is the effectiveness of unsolicited, electronic referrals to create awareness, trigger interest, and generate sales and it has an impact on tourists decision-making process. The wide use of the social media sites has helped managers realize the potential of a new technology, able to improve the traditional word-of-mouth communication, transforming it into an online viral way of communication with and between tourists(Kashem \& Uddin, 2013).Viral marketing and viral advertising refer to marketing techniques that seek to exploit pre-existing social networks to produce exponential increases in brand awareness, through viral processes like the spread of an epidemic. It can often be word-of mouth delivered and enhanced online; it can harness the network effect of the Internet and can be very useful in reaching a large number of people rapidly (Duan, 2010).

Viral marketing focuses on personal experience of the brand and taps into the power of tourists and their connections to other tourists. It can both improve brand advocacy and increase brand awareness, but also help generate sales (Kirby \& Marsden, 2006). The first to write about viral marketing was 
Douglas Rushkoff in his 1994 book "Media Virus." He suggested that if such an advertisement reaches a "susceptible" user, that user will become "infected" and then can infect other susceptible users (Patel, 2007).Viral marketing is a technique that avoids the annoyance of spam mail. It encourages users of a specific product or service to tell a friend. This would be a positive word-ofmouth recommendation.

Phelps, Lewis, Mobilio, Perry, \& Raman (2004); Mohsen \& Zahra (2013); Yadav, Agarwal, \& Singh (2014) summarize the types of viral marketing techniques as follow:

- Pass-along: A message which encourages the user to send the message to others. The crudest form of this is chain letters where a message at the bottom of the e-mail prompts the reader to forward the message. More effective are short, funny clips of video which people spontaneously forward.

- Incentivised viral: A reward is offered for either passing a message along or providing someone else's address.

- Undercover: A viral message presented as a cool or unusual page, activity, or piece of news, without obvious incitements to link or pass along. In Undercover Marketing, it is not immediately apparent that anything is being marketed.

- User-managed database: Users create and manage their own lists of contacts using a database provided by an online service provider. By inviting other members to participate in their community, users create a viral, self-propagating chain of contacts that naturally grows and encourages others to sign up as well.

According to Edgell, Ruf, \& Agarwal, (2000), tourism organizations must plan and target whomever they want to spread the word to about their activities, product or service for it to succeed and spread to other networks. Doing a viral marketing campaign would be much easier if the tourism destination understands the spreader's behaviour and the reason why they want to spread the word. Online negative viral marketing is a lot easier to believe than a positive one, particularly when a tourist has no clue or knowledge and he or she is a first-time user of the product or service.

The positive influence of viral marketing on the tourism organizations can be greatly, but it can also have a negative impact (Getz, 2008). As such, a long-time negative review of a tourism destination can result in damaging its image, which is where the importance of reputation management comes to mind.

(Coulter \& Roggeveen, 2012; Mejia-Trejo, Sanchez-Gutierrez, \& Vazquez-Avila, 2012; ) mentioned the following important elements of viral marketing:

- Gives away free products and services: The word "free" is the most strong and powerful word in a marketer's vocabulary. Under most viral marketing productions, they give away valuable products or services to attract attention which is why almost all businesses in Malaysia use this strategy to increase their company's productivity.

- Easy transfer to others: A viral marketing message must be able to easily transfer and copy through social websites, email, graphics, or software downloads. This is mostly done through the medium of internet because communication is easy and low-priced.

- Scales easily and effortlessly from small to very large: To spread like wildfire, the transmission method must be rapidly scalable from small to very large.

- Utilize motivations and behaviours: Quick and clever viral marketing plans take the advantage of common human motivations. Such as the desire to be "cool", popular, understood and loved; they create a message that "ticks" tourists and begs to be shared which then allows tourists to feel popular between their peers once they share the message.

- Utilizes existing communication networks: According to social scientists, each person has a network of 8 to 12 people in his or her network of friends, family, and associates. A person's large network may consist of scores, hundreds, or thousands of people, depending upon his or her position in society. A waitress, for example, may communicate regularly with hundreds of tourists in a week.

- Take advantage of other resources: The most creative and original viral marketing plans use others' resources to get the word out. For example, placing text or graphic links on others' websites (YouTube). 
From previous studies (Edgell, Ruf, \& Agarwal, 2000; Perry \& Raman, 2004; Coulter \& Roggeveen, 2012; Mohsen \& Zahra, 2013; Stavrakantonakis, Toma, Fensel, \& Fensel, 2013), this research develops the theoretical framework for this research (Figure 1). It indicates that there are four different viral marketing techniques that can be applied to tourism and hospitality organizations namely user-managed database, undercover, incentivised viral and pass-along. This model asserts that if those techniques applied, it will affect tourists' behaviours to become susceptible tourists. Those tourists will be infected and then can infect other susceptible tourists. Finally, this is will have either a positive effect or negative effects on tourism and hospitality organizations. In the next section, the researchers will identify the advantages of positive impact and the reasons for negative impact and how to overcome it.

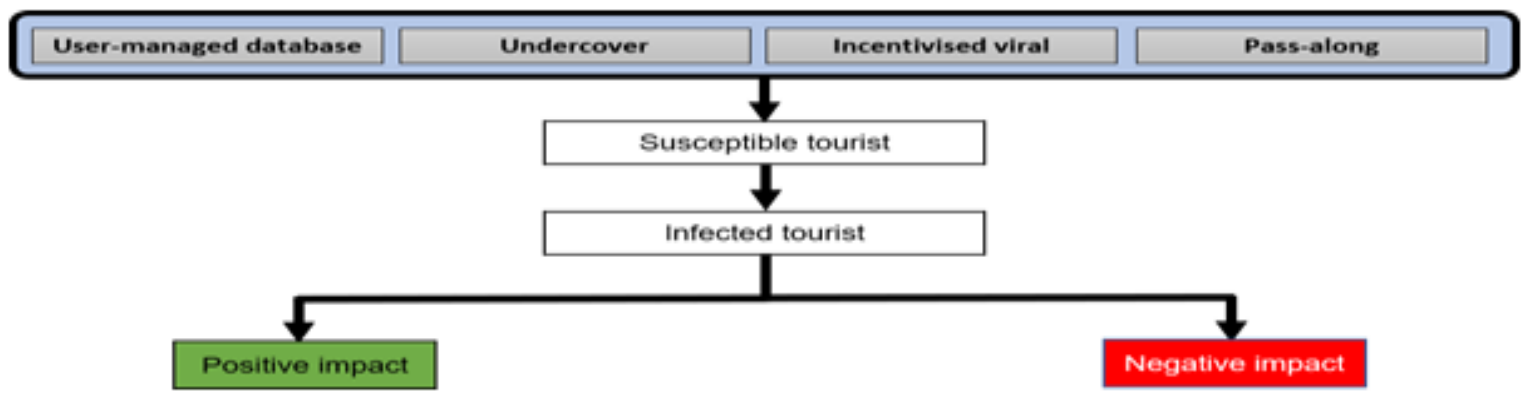

Figure1: Theoretical model of using viral marketing in tourism and hospitality organizations

\section{MeTHOdOLOGY}

This research is exploring the using of viral marketing in tourism and hospitality organizations through qualitative approach. Semi-structured interviews were conducted with a sample of 30 marketing managers in tourism and hospitality organizations (15 travel agencies and 15 hotels). Openended questions were used to investigate topics related to viral marketing with the aim of identifying the factors affecting viral marketing in tourism and hospitality organizations. Initially, a database of 70tourism and hospitality organizations was prepared based on specific characteristics of tourism and hospitality organizations in Egypt. However, only 30 tourism and hospitality organizations approved to participate in this research with a response rate of $43 \%$.

\section{Data Analysis}

First, interviewees were asked if they heard about the viral marketing term and if they could define it and an example. $77 \%$ of the respondents (23 Marketing Managers in tourism and hospitality organizations) reported that they heard about the term. On the other hand seven of them declared not being able to define it or give an example. They pointed out that viral marketing is a transmission of information between tourists as if it were a virus. Some interviewees mentioned that this communication is usually carried out exponentially and it reaches a large population quickly. It was indicated that this ability to reach many people quickly allows to achieve greater performance in advertising campaigns and improve the brand image. One interviewee reported that "Viral communication can generate positive feedback at a very small cost". Electronic media and new communication technologies, especially internet is named as the main means of transmission of messages between tourists. Some interviewees highlighted the difficulty of being able to control this transmission and indicate the lack of control over the message and its distribution. Regarding the use of viral marketing, several interviewees pointed out that it is widely used and affect tourists' opinions in tourism and hospitality organizations. On the other hand, some respondents think that viral marketing is done in a negative way.

The second question was about the terms WOM and eWOM and if they can define it or give an example.90\% of respondents (27) have an idea about those terms, although three of them they did not provide any definition or examples. In general, the respondents explained that WOM and eWOM consists of transferring a message from person to another. Moreover, 9 interviewees agree in pointing out the similarity between those terms and viral marketing. They revealed that those terms are considered as a form of viral marketing. Some respondents indicated that communication happens when there is a direct contact between the recipients rather than traditional means of communication. On the other hand, it is recognized that it can also be carried out by electronic means orby using both (online and offline). However, a negative recommendation which is made by some tourists might 
cause a danger to the organization. Respondents were asked about last viral marketing campaign they implemented. 11 marketing managers from tourism and hospitality organizations claimed to have ever carried out a viral marketing campaign. In order to understand the viral marketing benefits for tourism and hospitality organizations, respondents were asked about the degree of viral marketing impact on tourist attainment, tourist loyalty, brand image, return on investment of viral marketing campaigns, search for information by the tourists about the brand or the company, positive attitude of the tourists towards the brand and the re-purchase intention.

The variable "brand image" is considered the most important factor by the interviewed marketing managers affecting tourism and hospitality organizations. This agrees with (Latif, Islam, \& Noor, 2014)as they mentioned that the main contribution of viral marketing is to generate a positive or negative brand image. The second most marked variable is the "positive attitude of the tourists towards the brand or company". This agrees with (Sarabi \& Barakat, 2012) since the objective of viral marketing is to generate positive conversations between the targeted tourists. The third variable has an impact on tourism and hospitality organizations from viral marketing is "encouraging the search for information by the tourist about the brand or the company". There is a relationship between this variable and the previous two. This is since if tourists have acquired knowledge about specific service and have a positive attitude towards it, they will have a greater eager to seek information about the brand or the company.

On the other hand, 15 of the interviewed marketing managers in tourism and hospitality organizations reported that the return on investment from viral marketing campaigns is good. They explained that this investment does not require too much budget. However, the rest of the interviewed marketing managers pointed out that it was not easy to use viral campaigns as it needs investing a lot of money (e.g., making videos and other activities) and there is some uncertainty in achieving positive results.

Regarding the variables (tourist attainment, tourist loyalty and search for information by the tourists about the brand or the company), there are differences in the influence attributed to these variables which may due to the lack of direct experience in the use of viral marketing by some tourism and hospitality organizations. Finally, "the re-purchase intention of the services offered by a brand or company is having the lowest score by respondents which that indicates that tourism and hospitality organizations do not yet know the benefits of viral marketing in relation to buying behaviour. As indicated by (Sankaran, Kannan, \& Lakshmi, 2015), one of the challenges of viral marketing is no data about the success factors of viral marketing campaign.

Respondents were asked about the advantages of using viral Marketing for tourism and hospitality organizations. The answers of respondents will allow to analyse their opinions to understand the dissonance between the academic and professional perspective. The first advantage was called advantages related to the targeted tourists because they refer to the ability of the viral strategy to reach the tourists. Most of the respondents agreed on the following points as advantages of using viral strategy: provide an influence on the tourists purchase decision, decrease the needed time to reach of the target market and provide credibility to the services offered by tourism and hospitality organizations. The second advantage is the distribution of viral messages. Most of the respondents declared the ability of the viral strategy to reach many tourists and the ease of message distribution.

The third advantage is the different techniques of distributing viral message. There are different ways to distribute messages in viral marketing such asuser-managed database, undercover, incentivised viral and pass-along. Some of the respondents do not have an idea about those term. However, when explained to them, most of the respondents confirmed the positive impact of those techniques on attracting new tourists, reach difficult geographically tourists. The fourth advantage is generating an increase in brand awareness. Most of the respondents indicated that viral marketing can improve the positioning of the brand and improve knowledge about the brand or company. Finally, the fifth advantage is the effectiveness of viral campaigns more than traditional marketing.

On the other hand, the respondents were asked about the viral marketing disadvantages. The respondents indicated that the first disadvantage is some tourists might not have the willing to resend commercial messages to their contacts. The factors that motivate the acceptance and distribution of viral message may vary according to the different behaviours of tourists. Therefore, inappropriate use 
of viral Marketing can create unfavourable attitudes towards tourism and hospitality organizations. The second disadvantage is related to the viral marketing technical aspects. For example, messages blocked by virus and spam filters and risk of certain tourists being paid by some companies to spread their messages. The third disadvantage refer to the creation of viral marketing campaign. The respondents highlighted that motivating tourists to create and spread a viral message is difficult, absence of control over the message and its distribution.

\section{CONCLUSiONS}

Most of the interviewed tourism and hospitality organizations identified the meaning and importance of viral marketing. However, some of them asserted that they don't know the meaning of viral marketing as it is not widely used. The study concludes that a good viral marketing strategy allows an increase of the tourists' portfolio as each satisfied tourist will make recommendations to the friends. Tourism and hospitality organizations should use effective strategy by implementing the following four techniques: user-managed database, undercover, incentivised viral and pass-along. The tourism and hospitality organizations' ability to use social networks is also a key aspect. In this sense, the internet leader's opinion (such as bloggers, famous characters, experts, etc.) play a very important role in the distribution of messages on the Internet. The credibility of tourism and hospitality organizations is also one of the most important points for tourists when accepting recommendations.

Regarding the main advantages of the viral marketing for tourism and hospitality organizations, it has been found that the use of viral marketing can be very useful at the time of launching a new service to the market since it allows to achieve a great positioning. In contrast, effectiveness and assessment of viral campaigns are seen by tourism and hospitality organizations as a disadvantage. On the other hand, there are disadvantages for using viral marketing in tourism and hospitality organizations. Some tourists might not have the willing to resend commercial messages to their contacts. Viral marketing technical aspects such as messages blocked by virus and the creation of viral marketing campaign.

This research developed a final best practice model based on its literature and field study (Figure 2). The importance of viral marketing to tourism and hospitality organizations depends on the idea of creativity and the ability to get the public involved. This model indicate that tourists' personal experiences have a huge impact on viral marketing in tourism and hospitality organizations. Viral marketing is a powerful mean of promotion that can be used by tourism and hospitality organizations. This study concludes that using viral marketing techniques can improve the recommendation of the brand and increase the positioning in the market. Therefore, tourism and hospitality organizations should implement those techniques to take the advantage of the mobile phones and social networks. This requires tourism and hospitality organizations to include interactive means to interact with tourists and the introduction of new forms of advertising through expressing the individual needs of tourists. This research indicates that viral marketing can lead to positive impact on tourism and hospitality organizations such as Influence on the tourists purchase decision, reach difficult geographically tourists, different ways to distribute messages, decrease the needed time to reach of the target market, provide credibility to the services, reach many tourists, ease of message distribution, allow to attract new tourists and increase brand awareness. On the other hand, there are some problems that might face tourism and hospitality organizations in applying viral marketing techniques which leads to negative impacts such as difficulty of motivating tourists to create and spread a viral message, messages blocked by virus and spam filters, absence of control over the viral message, distribution of viral message may vary according to tourists' behaviours, certain tourists being paid by competitors and some tourists might not have the willing to resend commercial messages. The final model suggests that using the previous advantages in order to overcome the negative impact of viral marketing which can lead to the positive impact at the end.

The sample of this research is limited to tourism and hospitality organizations in Egypt. Therefore, this work opens the way for further research on viral marketing in other contexts or might be to focus on specific organizations in tourism or hospitality industry. Moreover, it would be interesting to analyse the perspective of tourists rather than professionals. Future research might develop tourists' profiles who are dedicated to viral marketing using quantitative approach. 


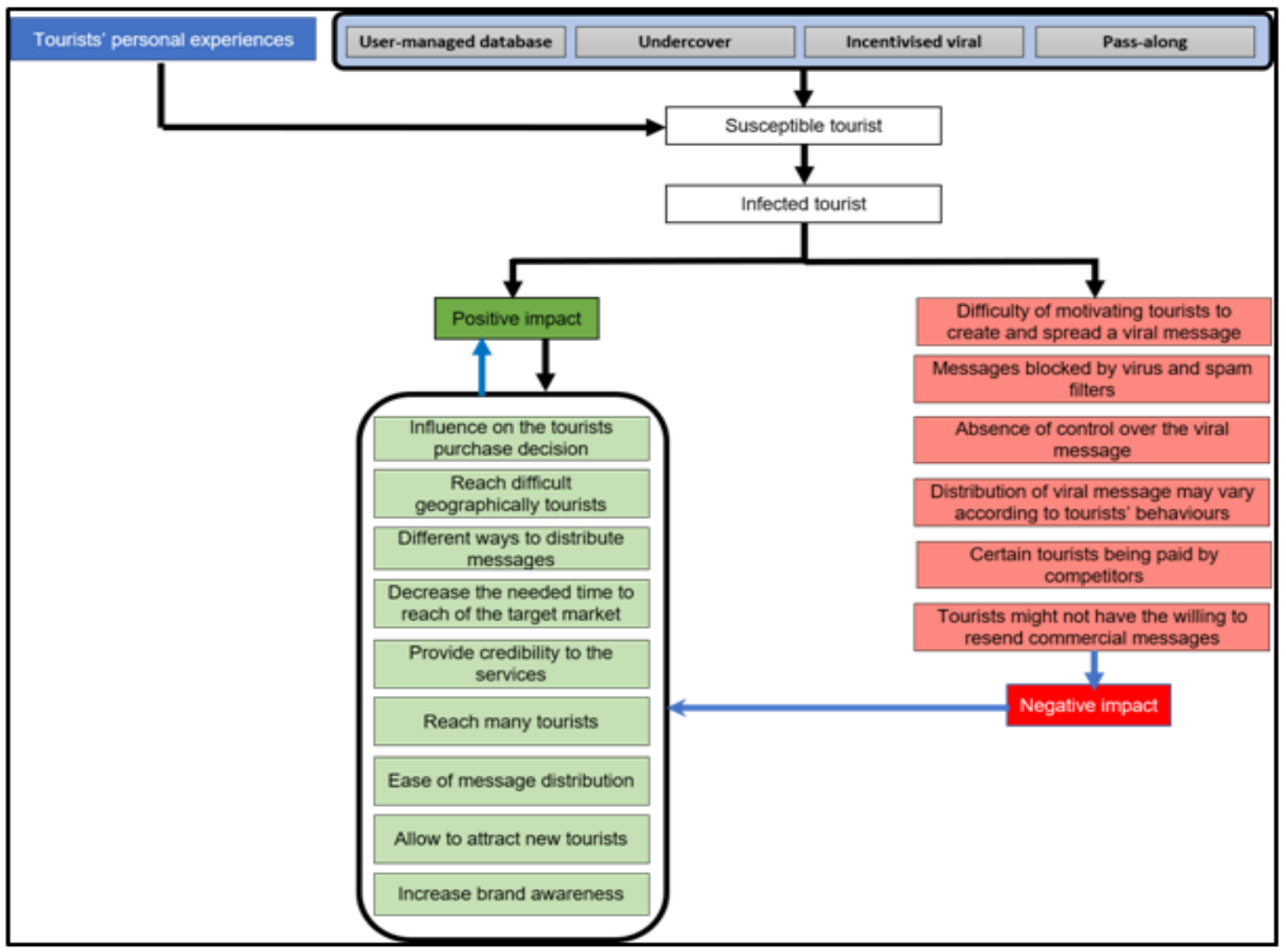

Figure2: A best practice model of using viral marketing in tourism and hospitality organizations

\section{REFERENCES}

[1] Alexandra, P., Claudia, I., \& Octav-Ionut, M. (2011). The impact of e-WOM spread through social networks on the decision making process: a Romanian online community analysis.

[2] Brown, T. J., Ham, S. H., \& Hughes, M. (2010). Picking up litter: an application of theory-based communication to influence tourist behaviour in protected areas. Journal of Sustainable Tourism, 18(7), 879-900.

[3] Chung, N., Lee, S. J., \& Han, H. (2015). Understanding communication types on travel information sharing in social media. Telematics and Informatics, 32(4), 564-575.

[4] Coulter, K. S., \& Roggeveen, A. L. (2012). "Like it or not": Consumer responses to word-of-mouth communication in on-line social networks. Management Research Review, 35(9), 878-899.

[5] Czepiec, H., Bryant, F., Roxas, J., \& Whitson, D. (2012). Teaching Students How to Create Viral Advertising/Marketing: A Case Study. Journal of Advertising Education, 16(1), 37-44.

[6] Duan, Q. (2010). Modeling and Analysis of End-to-End Quality of Service Provisioning in VirtualizationBased Future Internet.

[7] Edgell, D. L., Ruf, K. M., \& Agarwal, A. (2000). Strategic Marketing Planning for the Tourism Industry. Journal of Travel \& Tourism Marketing, 8(3), 111-120.

[8] Erragcha, N., \& Romdhane, R. (2014). New Faces of Marketing In The Era of The Web: From Marketing 1.0 To Marketing 3.0. Retrieved from http://jormonline.com/index.php/jorm/article/view/46

[9] Getz, D. (2008). Event tourism: Definition, evolution, and research. Tourism Management, 29(3), 403-428.

[10] He, H., \& Harris, L. C. (2014). Moral disengagement of hotel guest negative WOM: Moral identity centrality, moral awareness, and anger. Annals of Tourism Research, 45, 132-151.

[11] Kadyan, A., \& Aswal, C. (2014). New Buzz in Marketing: Go Viral. International journal of innovative research and development, 3(1).

[12] Kalyanam, K., McIntyre, S. H., \& Masonis, J. T. (2007). Adaptive experimentation in interactive marketing: The case of viral marketing at Plaxo. Journal of Interactive Marketing, 21(3), 72-85.

[13] Kaplan, A. M., \& Haenlein, M. (2010). Users of the world, unite! The challenges and opportunities of Social Media. Business Horizons, 53(1), 59-68.

[14] Kashem, M. A., \& Uddin, M. (2013). Viral Marketing Campign in Bangladesh: Present Scenario \& Away Forward. 
[15] Khan, M. A. (2012). Social Media's Influence on Hospitality \& Tourism Management. Retrieved from https://scitechnol.com/social-medias-influence-on-hospitality-3mqb.php?article_id=218

[16] Kirby, J., \& Marsden, P. (2006). Connected Marketing: The Viral, Buzz and Word of Mouth Revolution. Elsevier.

[17] Latif, W. B., Islam, A. K., \& Noor, I. B. (2014). Antecedents of Brand Image: A Case of a Developing Country. Asian Social Science, 10(19), 1.

[18] Litvin, S. W., Goldsmith, R. E., \& Pan, B. (2008). Electronic word-of-mouth in hospitality and tourism management. Tourism Management, 29(3), 458-468.

[19] Litvin, S. W., Goldsmith, R. E., \& Pan, B. (2017). A retrospective view of electronic word of mouth in hospitality and tourism management. International Journal of Contemporary Hospitality Management, 30(1), 313-325.

[20] Mejia-Trejo, J., Sanchez-Gutierrez, J., \& Vazquez-Avila, G. (2012). Popular Community Banks in Mexico: Designing the Measuring Tool of Innovation in Services for Competitiveness. International Journal of Economics and Management Sciences, 1(12).

[21] Mohsen, M., \& Zahra, A. D. (2013). PERSONAL MOTIVATIONS TO PASS ALONG ELECTRONIC MESSAGES FOR OTHERS (VIRAL MARKETING). Retrieved from https://sid.ir/en/journal/viewpaper. aspx?id=377003

[22] Morais, N. E., \& Mhando, J. (2012). Application of ICT in the Swedish Hopsitality a Tourism Industry: a study of viral marketing and word- of -mouth marketing concepts in relation to CRM. Retrieved from http://diva-portal.org/smash/record.jsf?pid=diva2:536908

[23] O'Reilly, T. (2005). What Is Web 2.0? Design Patterns and Business Models for the Next Generation of Software. Retrieved from O'Reilly Media: http://oreilly.com/web2/archive/what-is-web-20.html

[24] Patel, N. K. (2007). 'Internet Based Viral Marketing for Global Competition: The Road Ahead'. Retrieved from http://dspace.iimk.ac.in/bitstream/handle/123456789/56/163-170+.pdf?sequence=1\&isallowed=y

[25] Phelps, J. E., Lewis, R., Mobilio, L., Perry, D. K., \& Raman, N. (2004). Viral Marketing or Electronic Word-of-Mouth Advertising: Examining Consumer Responses and Motivations to Pass Along Email. Journal of Advertising Research, 44(4), 333-348.

[26] Rathore, A. K., Joshi, U. C., \& Ilavarasan, P. V. (2017). Social Media Usage for Tourism: A Case of Rajasthan Tourism. Procedia Computer Science, 122, 751-758.

[27] Sankaran, V., Kannan, D., \& Lakshmi, K. (2015). CHALLENGES OF VIRAL MARKETING WITH RESPECT TO BRAND REPUTATION. TIJ's Research Journal of Economics \& Business Studies - RJEBS, 4(6).

[28] Sarabi, A. A., \& Barakat, S. (2012). Positive Expectation: a Success Factor of Mobile Tourism Marketing. American academic \& scholarly research journal, 4(3), 37-43.

[29] Soteriades, M. (2011). TOURISM DESTINATION MARKETING. Retrieved from https://morebooks.de/ store/hu/book/tourism-destination-marketing/isbn/978-3-8443-9963-9

[30] Stavrakantonakis, I., Toma, I., Fensel, A., \& Fensel, D. (2013). Hotel Websites, Web 2.0, Web 3.0 and Online Direct Marketing: The Case of Austria. Retrieved from https://link.springer.com/chapter/10.1007/ 978-3-319-03973-2_48

[31] Yadav, S., Agarwal, N., \& Singh, A. (2014). Viral marketing as a promotional tool. Retrieved from http:// indianjournals.com/ijor.aspx ?target $=$ ijor :aca \&volume $=4 \&$ issue $=2 \&$ article $=017 \&$ type $=$ pdf

[32] Yeoh, E., Othman, K., \& Ahmad, H. (2013). Understanding medical tourists: Word-of-mouth and viral marketing as potent marketing tools. Tourism Management, 34, 196-201

Citation: Rehab Daif, Khaled Elsayed. "Viral Marketing Impact on Tourism and Hospitality Industry". International Journal of Research in Tourism and Hospitality (IJRTH), vol 5, no. 3, 2019, pp. 34-41. doi: http://dx.doi.org/10.20431/2455-0043.0503004.

Copyright: (C) 2019 Authors. This is an open-access article distributed under the terms of the Creative Commons Attribution License, which permits unrestricted use, distribution, and reproduction in any medium, provided the original author and source are credited. 